\title{
Characterization of the Rat Transforming Growth Factor Alpha Gene and Identification of Promoter Sequences
}

\author{
ANDREW J. BLASBAND,${ }^{1} \dagger$ KATHLEEN T. ROGERS,${ }^{2} \ddagger$ XIAORONG CHEN,${ }^{2}$ JANE C. AZIZKHAN,${ }^{1,3,4}$ \\ AND DAVID C. LEE ${ }^{1,2 *}$ \\ Lineberger Cancer Research Center ${ }^{1 *}$ and Departments of Microbiology and Immunology, ${ }^{2}$ Pediatrics, ${ }^{3}$ and \\ Pharmacology, ${ }^{4}$ University of North Carolina at Chapel Hill, North Carolina 27599-7295
}

Received 1 November 1989/Accepted 5 January 1990

\begin{abstract}
We have determined the complete nucleotide sequence of rat transforming growth factor $\alpha$ (TGF $\alpha$ ) mRNA and characterized the six exons that encode this transcript. These six exons span approximately 85 kilobases of genomic DNA, with exons 1 to 3 separated by particularly large introns. What had previously been thought to represent a species-specific difference in the size of the TGF $\alpha$ precursor (proTGF $\alpha$ ) is now shown to be due to microheterogeneity in the splicing of exons 2 and 3. This results from a tandem duplication of the acceptor CAG and gives rise to two alternate forms (159 and 160 amino acids) of the integral membrane precursor. Exon 6, which encodes the $3^{\prime}$ untranslated region of TGF $\alpha$ mRNA, also encodes, on the opposite strand, a small (approximately 200-nucleotide) transcript whose sequence predicts an open reading frame of 51 amino acids. Expression of this latter transcript does not appear to be coregulated with that of TGFa mRNA. Primer extension and S1 nuclease analyses of authentic TGF $\alpha$ transcripts revealed two major and multiple minor $5^{\prime}$ ends which span more than 200 base pairs of DNA in a G+C-rich region that lacks canonical CCAAT or TATA sequences. The $5^{\prime}$ ends of six independently derived cDNAs localized to five different sites in this same region. Restriction fragments that overlap these transcription start sites and extend approximately 300 base pairs in the $5^{\prime}$ direction faithfully promote transcription in vitro with HeLa cell nuclear extracts. In addition, they direct the expression of the bacterial chloramphenicol acetyltransferase gene in transient-transfection assays.
\end{abstract}

Transforming growth factor alpha (TGF $\alpha$ ) is an epidermal growth factor-related mitogenic polypeptide that is synthesized as a transmembrane glycoprotein precursor of 159 or 160 amino acids (termed proTGF $\alpha)(8,26)$. The external domain of proTGF $\alpha$ is processed at alanine/valine cleavage sites by an enzyme(s) whose activity is mimicked by pancreatic elastase (15). Complete cleavage results in the release of the 50-amino-acid mitogen that was first identified in the culture fluids of retrovirus-transformed and chemically transformed cells (30). However, cleavage is incomplete in many transformed cells, resulting in the accumulation of proTGF $\alpha$ at the cell surface (4), as well as in the release of larger, heterogeneously glycosylated forms due to selective cleavage at the carboxy-alanine/valine site $(5,15,29,41)$. The larger secreted forms of TGF $\alpha$ are also mitogenic (15), and recent studies have shown that proTGF $\alpha$ anchored to the cell membrane can bind to EGF/TGF $\alpha$ receptor on adjacent cells, thereby activating the intrinsic tyrosine kinase activity of the receptor $(4,46)$. These various observations suggest that the fully processed, 50 -amino-acid molecule is not the only physiologically important form of this growth factor.

Although TGF $\alpha$ protein and/or mRNA has been detected in a variety of normal tissues including pituitary (38), skin (6), decidua (14), and brain $(25,45)$ tissue, expression of this mitogen is distinguished by the fact that it is frequently induced or enhanced by neoplastic transformation. Thus, TGF $\alpha$ mRNA and protein are most prevalent and abundant in tumor cells $(1,7,47)$ and cells transformed by retroviruses, oncogenes, and chemicals $(10,27,37$; J. W. Grisham,

\footnotetext{
* Corresponding author

$\dagger$ Present address: Syntex Research, Palo Alto, CA 94304.

$¥$ Present address: Section on Cell Growth, Regulation and Oncogenes, Duke University, Durham, NC 27709.
}

M.-S. Tsao, D. C. Lee, and H. S. Earp, Pathobiology, in press). The expression of TGF $\alpha$ in both normal and neoplastic cells can also be regulated by defined agents. For example, estrogen treatment of primary differentiated rat mammary tumor cells in culture leads to both elevated expression of TGF $\alpha$ mRNA and increased secretion of the growth factor into the culture medium $(9,28)$. In addition, expression of this growth factor can also be regulated in a protein kinase C-dependent manner. Hence, the levels of TGF $\alpha$ mRNA are significantly induced by both the tumor promoter $12-\mathrm{O}$ tetradecanoylphorbol-13-acetate and epidermal growth factor in a chemically transformed rat liver epithelial cell line (GP6ac) (36), in cells of the bovine anterior pituitary gland (31), and in human keratinocytes $(6,34)$. The transient induction by TPA, which in GP6ac cells is at least partly due to increased transcription of the TGF $\alpha$ gene (36), may be distinguished from that of other transcripts including c-myc (20) and c-fos $(24,32)$ by both the time course of induction and the sensitivity to inhibition of protein synthesis (36). However, the molecular mechanism(s) responsible for either this induction or the transformation-linked enhancement of expression is unknown.

The finding that TGF $\alpha$ activity is elevated in many neoplastic cells as well as in human cancer patients $(1,47)$, together with the presumed role of TGF $\alpha$ in autocrine growth regulation, underscores the importance of defining the molecular regulation of its expression. A critical step in this process is the characterization of the gene and its promoter. A preliminary description of the human TGF $\alpha$ promoter was recently published (17). Here we extend this observation by presenting the complete nucleotide sequence of the rat TGF $\alpha$ transcript, as well as the intron-exon structure of the gene. In addition, we present a partial characterization of the rat promoter, which, in apparent contrast to its human counterpart, directs transcription 
from numerous sites spanning almost 250 base pairs of DNA.

\section{MATERIALS AND METHODS}

Cells and reagents. JM1 cells are rat hepatocellular carcinoma cells that were clonally derived from a chemically induced liver tumor (33). GP6ac and GP6TB cells are transformed cells that were clonally derived from a chemically transformed normal rat liver epithelial cell line, WB-FB344 $(12,43,44)$. The GP6ac line was selected for growth in soft agar in the absence of exogenous growth factors. The GP6TB line was derived from a tumor produced in neonatal syngeneic rats. Each of the above cell lines was maintained in monolayer in Richter's minimal essential medium supplemented with $10 \%$ fetal bovine serum. Poly(A) ${ }^{+}$RNA was $^{-}$ isolated from cells and tissues as described previously (14). Oligonucleotide probes and primers were synthesized by using a DNA synthesizer (no. 380B; Applied Biosystems, Inc., Foster City, Calif.).

Cloning of genomic and complementary DNAs. High-molecular-weight DNA was prepared from the liver of a normal Sprague-Dawley rat as described previously (3) and judged to be $>150$ kilobase pairs $(\mathrm{kb})$ in size by analysis on a $0.3 \%$ agarose gel. For construction of the cosmid library, DNA was partially digested with $\mathrm{MboI}$ and fractionated on 10 to $40 \%$ sucrose gradients, and fragments of approximately 50 $\mathrm{kb}$ were pooled and precipitated with ethanol. Size-fractionated DNA was ligated to cosmid vector pWE-15 DNA (Stratagene Inc., La Jolla, Calif.) that had been previously digested with BamHI and treated with calf intestinal phosphatase (Boehringer Mannheim Biochemicals, Indianapolis, Ind.). Ligation reactions were packaged in vitro by using Gigapak Gold extracts (Stratagene) and used to infect Escherichia coli 1046 . The resulting cosmid library, which consisted of approximately 500,000 CFU with an average insert size of $40 \mathrm{~kb}$, was plated and screened as previously described (40). Walking was accomplished by using end-specific, single-stranded RNA probes derived from the flanking SP6 and T7 promoters of pWE-15 as recommended by the manufacturer.

For construction of lambda libraries, genomic DNA was digested with either EcoRI, HindIII, or XbaI, and fragments ranging from 10 to $20 \mathrm{~kb}$ in size were purified from a low-melting-point agarose (Bio-Rad Laboratories, Richmond, Calif.) gel. Size-fractionated DNA was ligated to lambda (Charon 35) arms and packaged as described above. A library of partially digested EcoRI fragments of rat genomic DNA in lambda (Charon 4) was purchased from Clonetech, Palo Alto, Calif. Lambda libraries were screened with either ${ }^{32} \mathrm{P}$-labeled, nick-translated restriction fragments or end-labeled oligonucleotides.

cDNAs were synthesized by using either oligo(dT) or specific oligonucleotide primers and inserted into the EcoRI site of lambda gt10 by using EcoRI linkers as previously described (26). Clones containing TGF $\alpha$ cDNAs were identified as described above.

DNA sequence analysis. Genomic fragments and cDNAs were sequenced as double-stranded templates by the dideoxy-chain termination method of Sanger et al. (39) with $\left[\alpha-{ }^{32}\right.$ P]dCTP (Du Pont, NEN Research Products, Boston, Mass.) and T7 DNA polymerase (U.S. Biochemical Corp., Cleveland, Ohio). In all cases, the nucleotide sequence of overlapping regions was determined on both strands by using specific oligonucleotide primers.

Analysis of TGF $\alpha$ mRNA $5^{\prime}$ ends. TGF $\alpha$ mRNA $5^{\prime}$ ends were analyzed by using oligonucleotide primers that were 39 residues long. Primers were end labeled to high specific activity with T4 polynucleotide kinase and [ $\left.\gamma^{-32} \mathrm{P}\right]$ ATP (Du Pont, NEN). For primer extension reactions, labeled primer $\left(10^{5} \mathrm{cpm}\right)$ was hybridized to $10 \mu \mathrm{g}$ of poly(A) ${ }^{+}$RNA for $18 \mathrm{~h}$ at $42^{\circ} \mathrm{C}$ in $50 \%$ formamide $-40 \mathrm{mM}$ piperazine- $N, N^{\prime}$-bis $(2$ ethanesulfonic acid) (PIPES; pH 6.4)-400 mM NaCl-1 mM EDTA ( $\mathrm{pH}$ 8.0). After ethanol precipitation, annealed primer was extended with avian myeloblastosis virus reverse transcriptase (U.S. Biochemical) as described previously (22). Samples were treated with pancreatic RNase $(1 \mu \mathrm{g} / \mathrm{ml})$ for 30 min at $37^{\circ} \mathrm{C}$, extracted with phenol-chloroform, ethanol precipitated, and electrophoresed on a $6 \%$ polyacrylamide -8 $M$ urea gel in $1 \times$ TBE $(89 \mathrm{mM}$ Tris, $89 \mathrm{mM}$ boric acid, $2 \mathrm{mM}$ EDTA). The dried gel was exposed to X-ray film overnight at $-70^{\circ} \mathrm{C}$

S1 nuclease analysis was carried out essentially as described previously (13). Briefly, end-labeled primer was annealed to denatured EcoRI/XbaI-CAT plasmid (see Fig. 4B) and then extended by using the Klenow fragment of $E$. coli DNA polymerase I. The extension product was digested with HindIII, and the single-stranded probe was isolated by electrophoresis on a low-melting-point alkaline agarose gel. Probe $\left(5 \times 10^{4} \mathrm{cpm}\right)$ was hybridized to $10 \mu \mathrm{g}$ of poly $(\mathrm{A})^{+}$ RNA overnight at $42^{\circ} \mathrm{C}$ in a buffer containing $50 \%$ formamide as described above. After ethanol precipitation, samples were digested with S1 nuclease (Bethesda Research Laboratories, Inc., Gaithersburg, Md.), reprecipitated with ethanol, and analyzed by electrophoresis on a $6 \%$ polyacrylamide- $8 \mathrm{M}$ urea gel as described above.

Assays for transient expression of TGF $\alpha-C A T$ constructs. Subconfluent GP6ac cells were harvested by trypsinization, suspended in RPMI 1640 medium containing $10 \%$ fetal bovine serum, and transfected with TGF $\alpha$-chloramphenicol acetyltransferase (CAT) constructs by electroporation. Plasmid DNA ( $10 \mu \mathrm{g}$; purified by two sequential cesium chloride centrifugations) was transfected into $10^{7}$ cells in $0.5 \mathrm{ml}$ of RPMI medium-10\% fetal bovine serum at 1,650 volts by using a Zapper electroporation unit from the University of Wisconsin Medical Electronics Shop. Transfected cells were plated in Richter's minimal essential medium-10\% fetal bovine serum and $48 \mathrm{~h}$ later an extract of the cells was prepared and incubated for $3 \mathrm{~h}$ at $37^{\circ} \mathrm{C}$ with $\left[{ }^{14} \mathrm{C}\right]$ chloramphenicol in the presence of acetyl coenzyme $\mathrm{A}$, as described previously (21). The percent acetylation of chloramphenicol was quantitated by thin-layer chromatography followed by autoradiography and scintillation counting.

In vitro transcription. Nuclear extracts were prepared from HeLa-S3 cells as previously described $(2,11)$. In vitro transcription reactions were performed in a final volume of $25 \mu$ l containing $400 \mu \mathrm{M}$ each ATP, CTP, and UTP, $50 \mu \mathrm{M}$ $\left[\alpha{ }^{32} \mathrm{P}\right] \mathrm{GTP}(3,000 \mathrm{Ci} / \mathrm{mmol} ; 10 \mu \mathrm{Ci}$ per reaction; Du Pont, NEN), $1 \mathrm{mM}$ creatine phosphate, and $140 \mu \mathrm{M}$ EDTA. Transcription reactions were initiated by the addition of linearized plasmid template DNA and $15 \mu$ l of nuclear extract $(150 \mu \mathrm{g}$ of protein). The reactions were incubated at $30^{\circ} \mathrm{C}$ for $60 \mathrm{~min}$, and stopped by the addition of a mixture containing $8 \mathrm{M}$ urea, $0.5 \%$ sodium dodecyl sulfate, $10 \mathrm{mM}$ EDTA, and $10 \mathrm{mM}$ Tris (pH 8.0). A 494-nucleotide Sp6 transcript was included in the stop mixture as a control for sample recovery during processing. The samples were phenol-chloroform extracted twice, ethanol precipitated, and electrophoresed on a $4 \%$ polyacrylamide $-7 \mathrm{M}$ urea gel in $0.5 \times \mathrm{TBE}$. The gel was exposed to X-ray film overnight at $-70^{\circ} \mathrm{C}$ with an intensifying screen. Reactions were also carried out in the absence of radioactive label, and after 
phenol-chloroform extraction and ethanol precipitation the purified RNA was used as a template for primer extension reactions.

\section{RESULTS AND DISCUSSION}

Nucleotide sequence of rat TGFa cDNA. The $2.3-\mathrm{kb}$ rat TGF $\alpha$ cDNA originally isolated (3B1b [26]) was only a partial copy of the approximately $4.5-\mathrm{kb}$ mRNA. To obtain a full-length transcript, we constructed an oligo(dT)-primed cDNA library in $\lambda$ gt10 by using poly(A) ${ }^{+}$RNA from a chemically transformed rat liver epithelial cell line (GP6TB) that expressed relatively high levels of TGF $\alpha$ mRNA (Grisham et al., in press) (see Fig. 4A). The library was screened by using the original cDNA as a hybridization probe, and a $\lambda \mathrm{gt} 10$ clone that contained EcoRI fragments of 3.2 and $1.1 \mathrm{~kb}$ was identified. These fragments were subcloned into the plasmid vector pEMBL and sequenced on both strands by using the dideoxy-chain termination method and specific oligonucleotide primers. The nucleotide sequence of the $3.2-\mathrm{kb}$ insert (designated 22A3) predicted an open reading frame that was identical to that previously established for rat proTGF $\alpha(26)$, and this reading frame then determined the orientation of the insert. The sequence at the $5^{\prime}$ end of the 3.2-kb fragment was consistent with the addition of a synthetic EcoRI linker; the apparent 5' end of the actual cDNA was found to be identical to that of the original, 3B1b cDNA. The sequence of the 3.2-kb insert extended approximately 1 $\mathrm{kb}$ beyond the poly $(\mathrm{A})^{+}$addition site of $3 \mathrm{~B} 1 \mathrm{~b}$ and terminated at an apparently natural EcoRI site.

The 1.1-kb cDNA insert (designated 22A1) was found to contain, at one end, an EcoRI linker sequence followed by a poly $(A-T)$ tract of 60 residues and, at the other, an apparently natural EcoRI site. We presumed that the poly(A-T) tract defined the 3 ' end of this insert and that the 3.2- and $1.1-\mathrm{kb}$ inserts joined by the natural EcoRI site corresponded to an essentially full-length copy of the roughly 4.5-kb TGF $\alpha$ mRNA. This hypothesis was corroborated by the findings that (i) both the 3.2- and 1.1-kb inserts hybridized to a $4.5-\mathrm{kb}$ transcript on Northern (RNA) blots (data not shown) and (ii) the sequences contained at the $3^{\prime}$ and $5^{\prime}$ termini of these fragments are contiguous in genomic DNA (exon 6; see Fig. 2) and flank an EcoRI site (data not shown). Thus, the original cDNA clone, 3B1b, apparently corresponds to a transcript that is polyadenylated at a more $5^{\prime}$ site than is the 4.5-kb mRNA. It may correspond to a 2.3 - to $2.5-\mathrm{kb}$ species that is variably observed on Northern blots of tissue and cell RNAs, but is always present at significantly lower abundance than the $4.5-\mathrm{kb}$ transcript.

A composite nucleotide sequence of the rat TGF $\alpha$ cDNA as deduced from the $3.2-$ and $1.1-\mathrm{kb}$ inserts is presented in Fig. 1A. The transcript (whose structure is presented schematically in Fig. 1B) is marked by the presence of a short, $\mathrm{G}+\mathrm{C}$-rich $5^{\prime}$ untranslated region of approximately $150 \mathrm{nu}-$ cleotides and a long $3^{\prime}$ untranslated sequence of roughly 3,600 nucleotides. The latter region contains a CA repeat, which immediately follows the aforementioned $E c o R I$ site. It also contains, near the $3^{\prime}$ end, multiple $(A / G) T_{n}(A / G)$ tracts, including several ATTTA motifs which have been implicated in regulating mRNA stability.

Characterization of the rat TGF $\alpha$ gene. To characterize the organization of the rat $\mathrm{TGF} \alpha$ gene, we first identified genomic EcoRI fragments of 10 and $3 \mathrm{~kb}$ that hybridized to 3' untranslated-region probes derived from the $3.2-$ and $1.1-\mathrm{kb}$ cDNAs, respectively. We then walked in the 5' direction, using specific oligonucleotide probes to identify additional exons. Our initial walking was carried out with lambda libraries of partial or size-fractionated restriction fragments. Owing to the relatively large size of the gene, however, we subsequently constructed a cosmid library of overlapping 40to 50-kb fragments obtained by partial $\mathrm{MboI}$ digestion. In this way, we identified six exons which span approximately $85 \mathrm{~kb}$ of genomic DNA (Fig. 2) and which together account for all of the sequence contained in the full-length TGF $\alpha$ transcript. Exon 1 encodes the $5^{\prime}$ untranslated region and the $\mathrm{NH}_{2}$-terminal portion of the signal peptide. The remainder of the signal peptide is encoded by exon 2 . Exon 3 encodes the first two disulfide loops of the mature, 50-amino-acid growth factor, and exon 4 encodes the third disulfide loop and transmembrane domains. Exon 5 encodes the cytoplasmic portion of proTGF $\alpha$, and exon 6 comprises the entire $3^{\prime}$ untranslated region.

The intron-exon junction sequences are shown in Table 1. An examination of the intron sequence that immediately precedes exon 3 revealed that the donor CAG triplet is tandemly duplicated. This suggested that alternate splicing could result in the generation of two mature transcripts, the longer of which would contain an additional alanine residue at position 32 (relative to the initiating methionine) and presumably correspond to the cDNA cloned from a human renal-cell carcinoma (8). This suggestion was corroborated by the finding of $\mathrm{cDNAs}$ corresponding to both transcripts in the library constructed from GP6TB cells (data not shown). Thus, both 159- and 160-amino-acid forms of proTGF $\alpha$ are apparently synthesized in rat cells, although there is currently no evidence to suggest a functional distinction between these two forms of the molecule.

When used as a hybridization probe in Northern blot analysis, the original rat TGF $\alpha$ cDNA clone (3B1b) frequently detects, in addition to the $4.5-\mathrm{kb}$ mRNA, a small transcript of approximately $0.2 \mathrm{~kb}$. Using a variety of sense and antisense probes, we localized the sequences corresponding to this transcript to a 350-base-pair fragment that is immediately $5^{\prime}$ to the first polyadenylation site on the opposite strand from that of the TGF $\alpha$ coding frame (data not shown) (Fig. 1). As determined for the original 3B1b cDNA, as well as a genomic fragment, the nucleotide sequence of this region predicts a single open reading frame of 51 amino acids. However, the full-length $22 \mathrm{~A} 3 \mathrm{cDNA}$ shown in Fig. 1 contains a 9-base-pair substitution within this region, with an AAGCAGGAG sequence being replaced by the sequence GAGCATGCA. This not only results in the substitution of a Lys-Gln-Glu tripeptide with a Glu-His-Ala sequence at positions 3 to 5 of the putative protein, but also creates an alternate reading frame of 45 amino acids beginning at position +11 relative to the aforementioned ATG. Since the ATG of this alternate reading frame is $3^{\prime}$ distal to the first and is not present in our genomic clone or in the 3B1b cDNA isolated from feline sarcoma virus-transformed Fischer rat embryo fibroblasts, we hypothesize that the $0.2-\mathrm{kb}$ transcript encodes the 51-amino-acid protein described above. This putative protein contains an unusual stretch of asparagine residues and two potential overlapping glycosylation sites (Fig. 3A).

A small (350-base-pair) transcript was recently shown to be expressed from the antisense strand of the human TGF $\alpha$ gene (18). This transcript, which was broadly mapped to the $3^{\prime}$ untranslated region, was found to be expressed in an inverse manner with respect to that of TGF $\alpha$ mRNA. In contrast, expression of the $0.2-\mathrm{kb}$ transcript in rat cells is not obviously coregulated in either a positive or negative manner with that of TGF $\alpha$ mRNA. Thus, the $0.2-\mathrm{kb}$ transcript is 
A

CCGGGAGCGCGGTCGTCCCTCCGCCCGCGCGCCGGGGGCCGCCCTETCGCCTGCGCCIIITICCCCCGCGCACACCGCGGCGGCGCGC

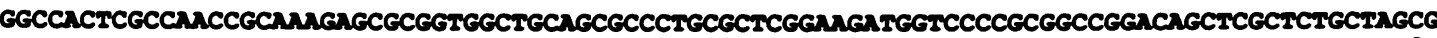

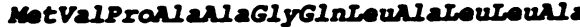

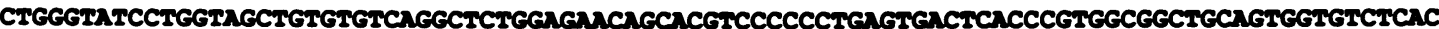

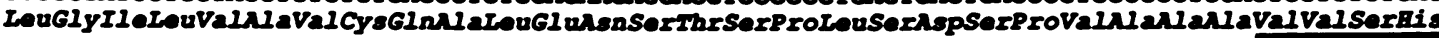

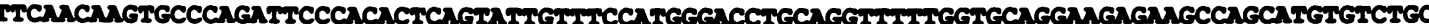

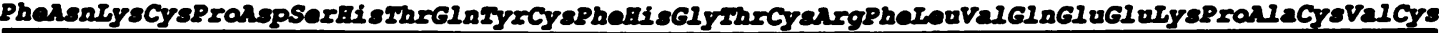

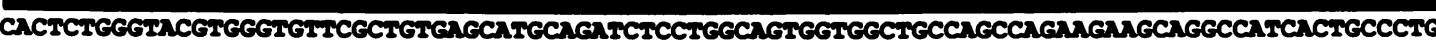
BisSerG1 yTy

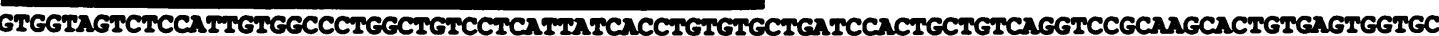

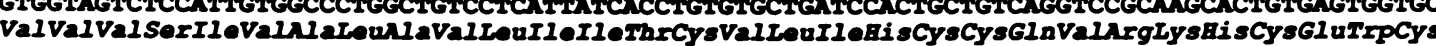

CGTGCCCTCGTCTGCAGACACGAGMGCCCAGCGCCCTCCTENAGGMGGACTGCCTGCTGCCACTCTGAGACAGTGGTCTGMAGATCC

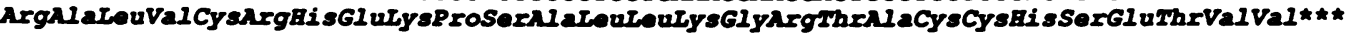

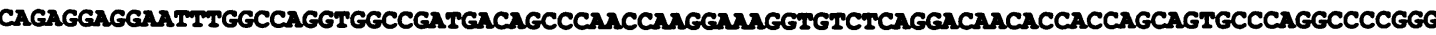
ACATGCTGGGAACCTTCCCCCTCAATGTACNACCACCTGGGCAGCTCTCTGTCCTIMACGAGCTTCAAAACTGTGTGATAAAGGTGCC

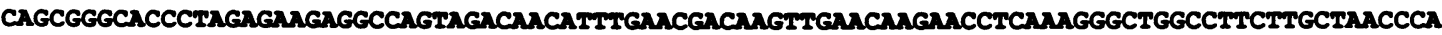
CACCNAGAGGCTGTCCGTGGACTCCNAATETTTCTTCTCCATGGGCCGTCTANCCCCCCACAGAGACTCCACGCTTGGTGTACAAAAT GGACAAGGGAACATCTATTGTCCTITGAAACACCATGGCCCCGGCATGAGCCCTGACATCTCCTCAAACGGTGGCAGGATGATGTG TCTTATGTATIAGGTGGATGACGCGTITIGTITGTATTCTCTIYATGTCAGTATCGGGCATCCATGTPAATGATCCACGAGCGGTGGC

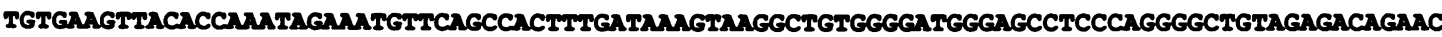
TCNAMGTGCATTCTGCTGGMACCNACTGCTACCAGGAGGTETGCCCACTMAGAAGGANGTCCCTGGATATATGCTGTGGCAAAG

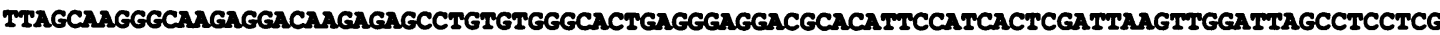
TGAGCCCAGCTCCAGCATCAGCCATGAGCCGTGGGCANATCCGTGNGGTGACCCCCTCTYTATTGGTTTCTGCTCATITTTAGAAGA

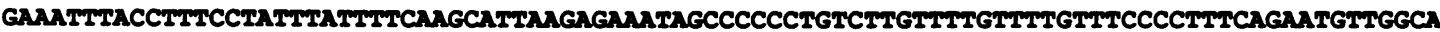
TrACTAATGNATCGCTACCAAGCCTCTCCACTCCCCTCCGGGGMGGAGCTATGTTCCCTGAGCACTGGAGGGGCTCTGACCCATTGA

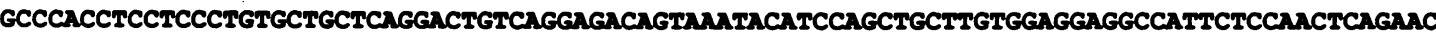
TTAAAGGGCCTCCACCCTCCAGAGCCTITAACGTAACGTCAGGNAAGGGGTGITTGACATACCAAATTCTCAGCAAGTTCTGCCTGTT CCTCATTCTTCTCCATTCCACCTTTCTCTGTGATGITITCTHTCTCATATGACCTAGATATCAATCTGCCCAGGTCTTAACCCTGGCT CССTTTGTTAACAATGCCTCAAGCTCCACNAGAAGAAGTGGGTTGGTTCAGTGCTGACCTCTANCTACTCAGTCGACGTGGCTCCAGGC GGAAATCGTCACTTGTGTTGTIATTATTATTATTATTTTGGTTTGATGTPTPATCTTGTTTTGTGAGACAAGGTCTTGCTGTGTAGCCCA GGTTGGCCTTGAATTAAGATCTGCATGCTCCAGCAICCTGAGAGCTGGGTTACTGGTGACAGCACCGCACCCAGCAGAGTCTTTACG GTTATTAAAGAAGACAGGTTAAGTTTGCTTTCCTTGGGTCGTGCATGTGGGTCAAGGCCAMTGTAGCCTGCTGCTCAGACACCCATCGA ССTCACTGGACGTTGGCCTCTATTGGGCCCCAATGCAGACCCTGTATGAAGTACTAGCTCACCAGGGCCAACACAAAGGAGGGGCTT GTTTTAATTTAGTTCACACCGTPAGCTTCCGATGATAAGTCTTYCCTGGTCTGTTGGAAGCTCCTGGGTGTCTGACTTCTTITAAAGAGT TTGAACTGATATCAAATATCATTGGGATTTCTTCACCTAGTGTCCCATCCTGMGATATTACCATGCAAGACTCAGCAGAGGTGGGA AAGTTAGTACAAACCTTTAATGGGGAGGAGAGGATCTTGGGAGACCTCAGCTTPAGTGTCTGACATTCCGGTCTCAGGTCCAGCC AGTCACAGCAGCCA GTACCATCCCAGTACCCATACACAGATGCAGCCGGCTCAAACGTCTCCCAGAATGCCTTCCCCACCAGTCATACC CTCTGAAGAGTCAGAAGCTGAGACTAAGTTGAGGCAAATCTGGTTGGCATCGTCCTGCCCTGACATAAGACAGCCCTGCTTCTTTGGTG ACTCTGATTCTTGGAATCAGACAAATGCTGACAGCACANATCTCACAGCACAGTTAGACCTGGGTAGCTGTCCCAGCACCTCCTGTCAG GTCACACTGGCCCTCTTGATACTCAGTGCAGCTACTGAGTCAGGAGCACTCGTCAGCAGACACACAGGTCAGTGGACAGTGACTCAGAGG ACTGTGACATTCCCATTAAATGGATTGAAATTAATTCTGGAGTCATTAAGAGAGCTCAGTTAAGATGGCACTTACCAATATCCCTGAG

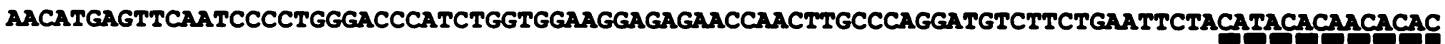
ACACACACACGCACACACACACACACACACACACACCCCTCTAGCTGTAACTTTAAACACATGATGGGACATGTTCTCTCCATGCAAAAC TACAATGGGGACTCAGTCTGAAAGATAGATTCTAGGTGGACATACGCAGACCCAAACCATAAGTCAGTTTGTCATGTGCCCAGAAAAAGG TGGTAACAATAGTCCCAATGTCCTTTTTCTCCTAAAAAGGTTGTGGGAGGCATGGTTGGTACCCACCCACCCACACTGGTGAGGGAGT GACTGTGTCCCTGAGTCTTAGATGGTGATGTTGTTCCCTGCAAGTCCCCAGGCCAGGTTTCCTAGTGCCTGTGAGCCACTAGGTGGACCG GCAACACGCTGACACTGCCTACAGGCCCCAGTCCCATGGTGATAGTAAGGTTACCTCTCTCAAAGGCCAAGGGGAGGCACATGAGACA ACACGTTTTTCACACAGGTTTCACTGTATAGCCCAGGCCAGCCTCAAACCCATGATTCCCCTGCCTCAGCCTACTGGGTTACAGGTGTG CACTGCCATACCTGGCTCACGTTTGTTTTTTAATGTTCTGGTGTAACATGTATTCCCTGAAGCCATTGATCTATCTCAAAGACACAGTGT TGTACGCATACATGTGCGCACGTACACACACCAAACTGGAAGCGACCCCTCTCCATAGTGTGATAAGTTTATTATAAGTTTATTATAAG GACCCTATGCTGTTTPTAGAACTCATCTTTCTGACTTCTGTATATGATGCACTGAAGGTTAATATGTAATATTTTAATTTATTTMATGTG GTAAGTTATTTTGGTTTCTGTAATGTATTAATGTGATTAGAAGCTTTTTTCCTTAATATCTGAATTATACTTAAAGAGTAGTGAGGAA TATAAGATACTGTTGTGTATTGTACCTTGTTTGGAGGATGAGGAATGAACCCTTTTTTPTTTCCT (A) 60
180 


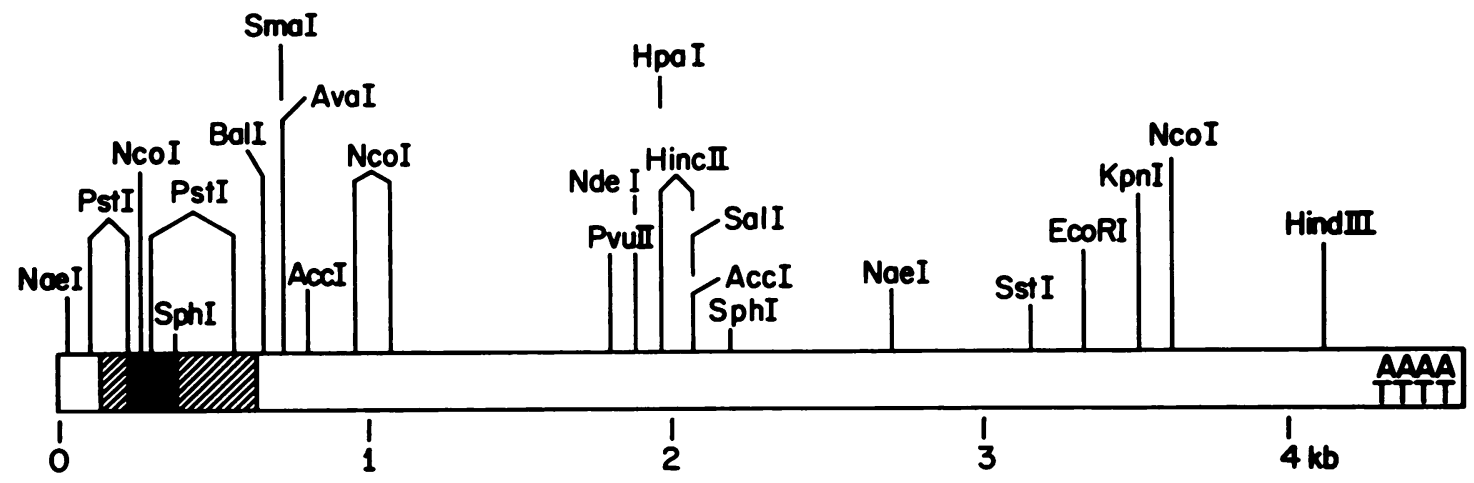

FIG. 1. (A) Complete nucleotide sequence of a full-length rat TGF $\alpha$ cDNA. The predicted sequence of the 159-amino-acid precursor is shown, and the portion corresponding to the mature, secreted 50-amino-acid growth factor is delineated by a heavy underline. The two predicted polyadenylation signals in the $3^{\prime}$ untranslated region are underlined, and an alternate site of polyadenylation observed with a previously isolated cDNA (26) is indicated $(\nabla)$. The presence of a CACA repeat is marked by a broken underline, and the location of an open reading frame that is encoded by a small transcript expressed from the opposite DNA strand in exon 6 (see text and Fig. 2) is indicated by arrows. This sequence will appear in the EMBL, GenBank, and DDBJ nucleotide sequence data bases under the accession number M31076. (B) Partial restriction map of the 4.5-kb rat TGF $\alpha$ cDNA. Symbols: the mature, 50-amino-acid growth factor within those sequences. The poly(dA-dT) tract at the 3 ' end is indicated.

expressed in many rat tissues and cell lines, including those that express TGF $\alpha$ mRNA at both high and low levels (data not shown). In addition, unlike that of TGF $\alpha$ mRNA, expression of the smaller transcript is not appreciably induced in a transformed rat liver epithelial cell line, GP6ac, $8 \mathrm{~h}$ after the addition of $100 \mathrm{nM}$ TPA to the medium (Fig. 3B). That the $0.2-\mathrm{kb}$ transcript is polyadenylated is suggested by the finding that its detection is enhanced in oligo(dT)-purified RNA derived from a rat hepatocellular carcinoma line (JM1), as well as from the cervical spinal cord, a site of relatively high TGF $\alpha$ mRNA expression in the normal adult rat (Fig. 3B).

Analysis of TGF $\alpha$ mRNA 5 ' ends. In the course of screening the oligo(dT)-primed cDNA library, we characterized the $5^{\prime}$ ends of three TGF $\alpha$ cDNAs that appeared, on the basis of size, to be essentially full-length. The $5^{\prime}$ ends of these cDNAs mapped to three different positions within 75 bases upstream from the $3 \mathrm{~B} 1 \mathrm{~b} / 22 \mathrm{~A} 35^{\prime}$ end (see Fig. 7). Additionally, we constructed a second cDNA library from GP6TB RNA by using a specific primer that was designed to hybridize to the 5' untranslated region of TGF $\alpha$ mRNA, immediately upstream from the initiating ATG. Screening of this library with oligonucleotide probes corresponding to the 5 ' untranslated sequence failed to yield any clones larger than 250 base pairs in length (data not shown). The $5^{\prime}$ end of the longest clone mapped to a position 115 nucleotides upstream from the common $3 \mathrm{~B} 1 \mathrm{~b} / 22 \mathrm{~A} 35^{\prime}$ end (see Fig. 7).

The above findings suggest that rat TGF $\alpha$ mRNA comprises a collection of transcripts with heterogeneous $5^{\prime}$ ends.

CDNA

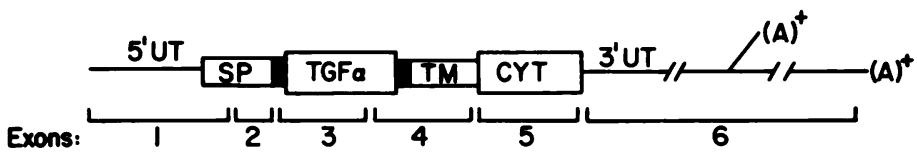

\section{Genomic}

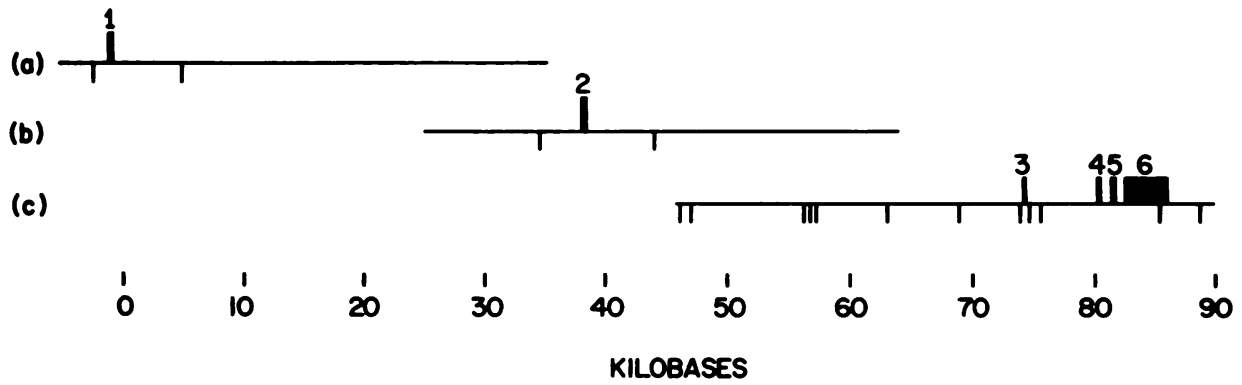

FIG. 2. Exon-intron structure of the rat TGF $\alpha$ gene. The functional domains of the rat TGF $\alpha$ mRNA, as deduced from the cloned $c D N A$, are indicated together with the exon organization as revealed by sequence analysis. The approximate locations of these exons (bars) in overlapping cosmid (a and b) and $\lambda(\mathrm{c})$ genomic clones are indicated. The positions of EcoRI sites are marked by vertical lines. A complete map of EcoRI sites is shown for the $\lambda$ clones, but only the positions of sites that flank exons are shown for the cosmid clones. 
TABLE 1. Intron/exon junction sequences

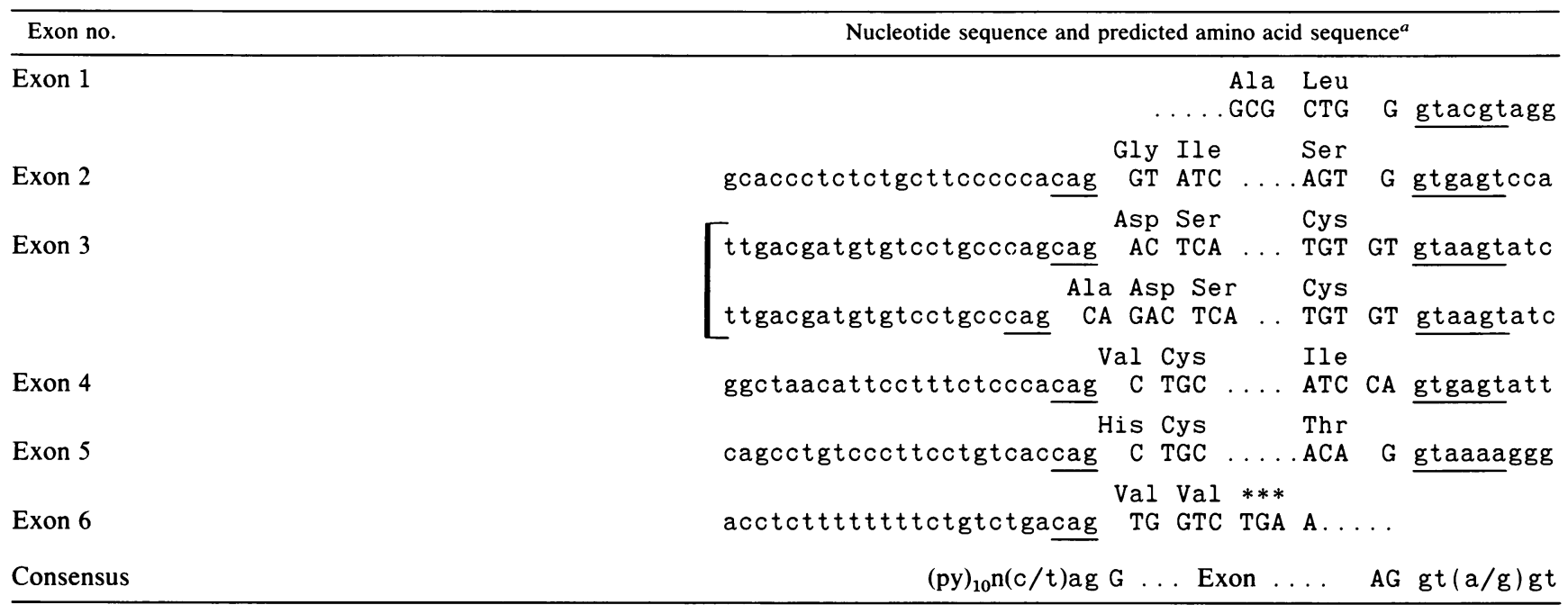

${ }^{a}$ The nucleotide sequences flanking the intron/exon junctions of the rat TGF $\alpha$ gene are indicated along with predicted amino acid sequence. The intron sequence is indicated by lower case letters, and the exon sequence is indicated by capital letters. Splice acceptor and donor sequences are underlined.

To directly address this possibility, we carried out primer extension and $\mathrm{S} 1$ nuclease analyses of poly $(\mathrm{A})^{+}$RNA from two rat cell lines, GP6TB and JM1, that express TGF $\alpha$ mRNA at relatively high levels (Fig. 4A). Primer extension was carried out with two different oligonucleotide primers, RT1 and RT3. RT1 spans sequences present in exons 1 and 2 and is the more distal primer, whereas RT3 is complementary to sequences wholly contained in exon 1 , beginning 41 nucleotides downstream from the $3 \mathrm{~B} 1 \mathrm{~b} / 22 \mathrm{~A} 35^{\prime}$ end (Fig. 4B). When RT1 was used for primer extension with poly $(A)^{+}$ RNA from GP6TB cells, we observed a predominant band of approximately 112 nucleotides, along with a more distal cluster of products ranging in size from 230 to 330 nucleotides (Fig. 4C, lane 2; see also Fig. 6B). Within this cluster was a predominant transcript(s) of approximately 244 bases. A similar pattern of upstream products was observed when RT3 (which is upstream from, and therefore does not detect, the aforementioned 112-base product) was used as the primer. Thus, RT3-primed extension of both GP6TB and JM1 RNAs yielded a large number of products ranging from 100 to more than 200 bases in length, with predominant bands of approximately 86 to 88 nucleotides. None of these products were observed when the RT1- and RT3-primed extensions were carried out by using poly $(\mathrm{A})^{+}$RNA from either normal rat liver (Fig. 4C, lanes 2 and 3) or a nontransformed rat liver epithelial cell line, WB-F344 (27) (data not shown), neither of which expresses TGF $\alpha$ mRNA at appreciable levels.

To confirm that the many distal primer extension products described above correspond to authentic 5 ' ends, we used an EcoRI-XbaI subclone of the rat genomic sequences to analyze endogenous GP6TB RNA by $\mathrm{S} 1$ nuclease protection analysis. End-labeled RT3 was annealed to the denatured subclone and extended by using the Klenow fragment of DNA polymerase I. After digestion with HindIII, a singlestranded, 505-nucleotide probe (Fig. 4B) was isolated from a denaturing alkaline agarose gel. Hybridization of this probe to GP6TB poly(A) ${ }^{+}$RNA yielded an essentially indistinguishable pattern of $\mathrm{S} 1$ nuclease-resistant bands to that obtained by primer extension with RT3 (Fig. 4C, compare lanes 6 and 8 ). As in the case of the extension products, these S1-resistant bands were not observed with normal rat
A

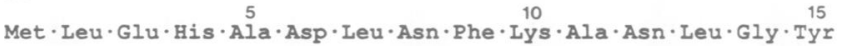

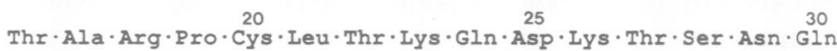

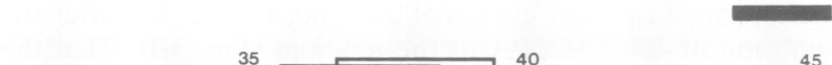

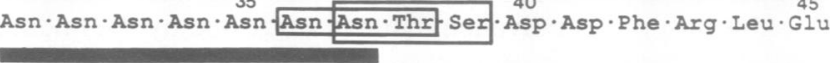
Pro $\cdot$ Arg $\cdot$ Arg $\cdot$ Leu $\cdot$ Ser $\cdot$ Ser

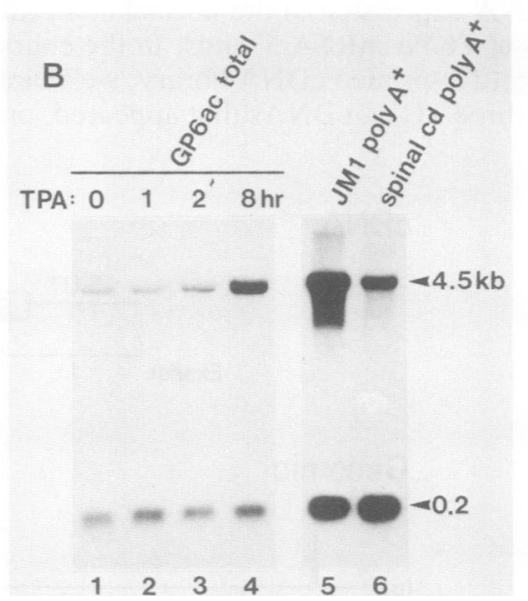

FIG. 3. (A) Predicted amino acid sequence of an antisense transcript. This open reading frame is encoded by a small transcript that is expressed from the opposite strand to that of TGF $\alpha$ in exon 6 . The position of this open reading frame is illustrated relative to the TGF $\alpha$ 3' untranslated sequence in Fig. 1A. An asparagine repeat is underlined, and two overlapping glycosylation consensus sites are boxed. (B) Expression of the antisense transcript. Northern blots of total (lanes 1 to 4 ) or poly $(A)^{+}$(lanes 5 and 6) RNA (10 $\mu \mathrm{g}$ per lane) probed with the cloned 2.3-kb rat TGF $\alpha$ cDNA (26). GP6ac cells were treated with $100 \mathrm{nM}$ TPA for $0,1,2$, or $8 \mathrm{~h}$ prior to harvest. RNAs were prepared and analyzed as previously described (14). The approximate sizes of the observed transcripts, as judged by reference to RNA markers of known size (Bethesda Research Laboratories) is indicated. 


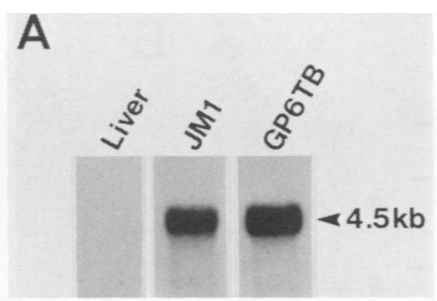

B
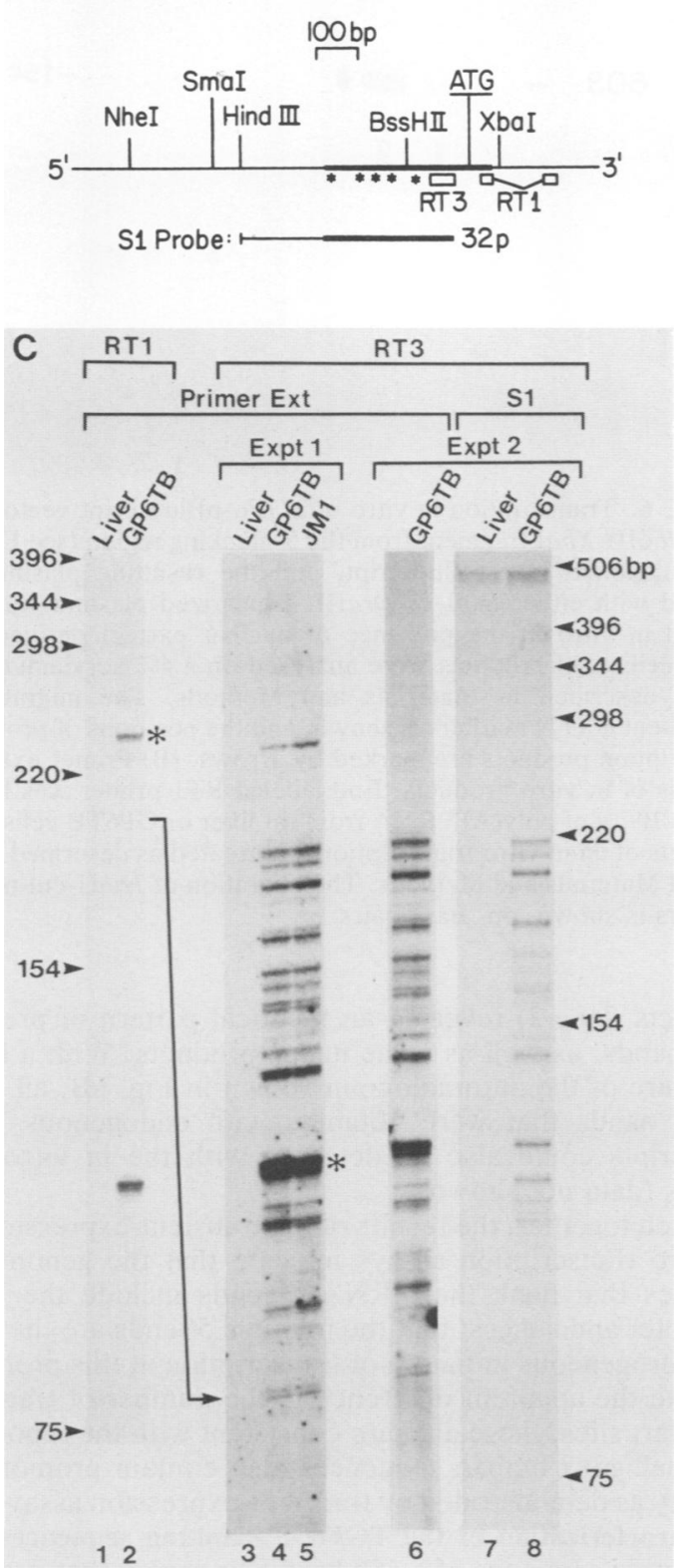

FIG. 4. 5'-End analysis of endogenous rat TGF $\alpha$ mRNA. (A) Expression of rat TGF $\alpha$ mRNA. Northern blot analysis of poly(A) ${ }^{+}$ RNA (10 $\mu \mathrm{g}$ per lane) probed with the cloned 2.3-kb rat TGF $\alpha$ cDNA (26). RNAs were prepared from liver and JM1 and GP6TB cell lines as previously described (14). The position of the $4.5-\mathrm{kb}$ TGF $\alpha$ transcript is indicated. (B) Preparation of primer extension and S1 nuclease probes. A partial restriction map of genomic DNA at the $5^{\prime}$ end of the rat TGF $\alpha$ gene is shown. The approximate locations of cDNA 5 ' ends are marked (*), and the extent of exon 1 liver poly(A) ${ }^{+}$RNA. Although we have not confirmed the proximal $5^{\prime}$ end (the 112-nucleotide product referred to above) by $\mathrm{S} 1$ nuclease analysis, its authenticity is confirmed by the results of in vitro transcription studies described below. Together with the primer extension data, these results indicate the absence of intervening sequences $5^{\prime}$ to the initiation codon, and demonstrate multiple $5^{\prime}$ start sites spanning a distance of more than 200 base pairs. Calculating for the positions of the primers, predominant $5^{\prime}$ ends are found 58 and 188 to 190 nucleotides upstream from the initiating codon, but minor $5^{\prime}$ ends extend to almost 300 nucleotides (see Fig. 7). This is in contrast to a recent report describing a single $5^{\prime}$ end for the human TGF $\alpha$ mRNA that is 62 nucleotides $5^{\prime}$ of the initiating codon (17). The latter appears to be in an analogous position to that of the predominant $5^{\prime}$ end noted at position -58 (see above).

Characterization of promoter activity. To determine whether the DNA sequences that flank the $5^{\prime}$ ends of rat TGF $\alpha$ mRNA have promoter activity, we constructed a series of vectors that placed the bacterial CAT gene adjacent to various genomic fragments (Fig. 5A). These genomic fragments contain variable amounts of $5^{\prime}$ sequence but end with a common $3^{\prime}$ terminus at the BssHII site (see Fig. 7). The latter was chosen to exclude the TGF $\alpha$ translational initiation codon. Promoter activity was then assayed indirectly by measuring CAT activity in cell extracts prepared $48 \mathrm{~h}$ after electroporation of vectors into the chemically transformed GP6ac cell line. The results (Fig. 5B) demonstrate that vectors containing the 410-base-pair HindIII-BssHII and 480-base-pair SmaI-Bss HII fragments displayed measurable promoter activity in this transient-expression assay, although in both cases the activity observed was lower than that obtained with pSV2-CAT. In contrast, the inclusion of additional upstream genomic sequence reduced the CAT activity to a level equal to or lower than that observed with the promoterless pUC-CAT vector. The latter appears to direct a low level of transcription from a cryptic promoter within vector sequences. Thus, both the 680 -base-pair NheI$B s s$ HII fragment and 1,900-base-pair EcoRI fragment lacked demonstrable promoter activity, raising the possibility of upstream transcriptional repressorlike sequences. Finally, it should be noted that the experiment shown in Fig. 5 was repeated several times in both GP6ac and other transformed rodent and human cell lines, with analogous results (data not shown).

The potential promoter activity of the immediate upstream flanking sequences has also been tested by assaying their ability to direct transcription in vitro. The HindIII-XbaI fragment (Fig. 4B), which includes all of the mapped 5 ' ends

is indicated by the heavy line. The approximate positions of the RT1 and RT3 primers are illustrated, along with the structure of the S1 nuclease probe. (C) Primer extension and S1 nuclease analyses of endogenous TGF $\alpha$ transcripts. RT1 and RT3 primers were hybridized to $10 \mu \mathrm{g}$ of rat poly(A) ${ }^{+}$RNA from either liver or GP6TB or JM1 cell lines. The S1 nuclease probe was generated by using the RT3 primer and hybridized to $10 \mu \mathrm{g}$ of $\operatorname{poly}(\mathrm{A})^{+}$RNA from liver or GP6TB cells. The positions of Hinfl-cut pBR322 markers are indicated, although the primer extension and $\mathrm{S} 1$ nuclease products were actually sized with reference to either RT1- or RT3-primed dideoxy sequencing reactions included on the same $6 \%$ polyacrylamide-urea gels (not shown). The extended arrow and asterisks indicate the relative positions of RT1- and RT3-primed extension products, respectively, that appear to share the same $5^{\prime}$ terminus. Note that the primer extension and $\mathrm{S} 1$ nuclease products in experiment 2 were electrophoresed in parallel on the same gel. bp, Base pairs. 

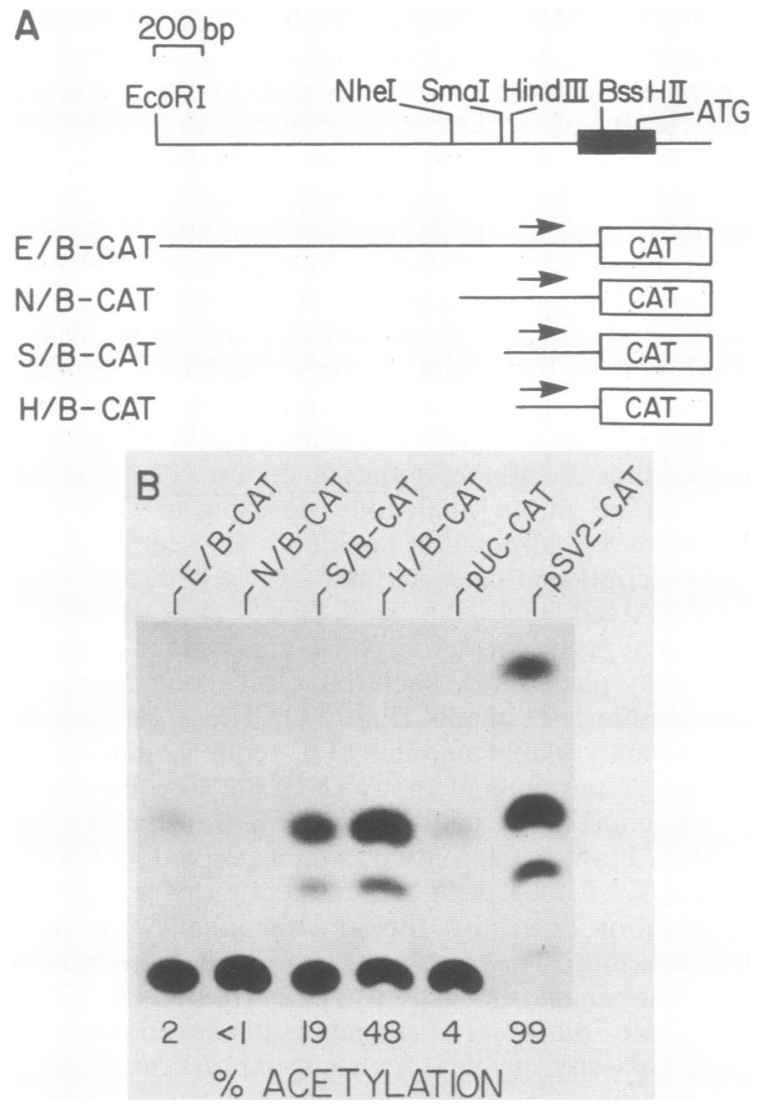

FIG. 5. Transient expression of TGF $\alpha$-CAT constructs. (A) Partial restriction map of genomic DNA at the 5 ' end of the rat TGF $\alpha$ gene. Exon 1 is shown $(\square)$, and the position of the translational initiating ATG is indicated. The construction of chimeric TGF $\alpha$ CAT plasmids is illustrated, and the extent of genomic sequence inserted before the CAT gene is indicated. Arrows designate the direction of transcription. bp, Base pairs. (B) GP6ac cells were electroporated with $10 \mu \mathrm{g}$ of plasmid DNA and, after $48 \mathrm{~h}$, harvested for determination of CAT activity as described in Materials and Methods. pUC-CAT is the parental promoterless construct, and pSV2-CAT contains the simian virus $\mathbf{4 0}$ early promoter. The percent acetylation was determined by counting the relevant portions of the thin-layer chromatography plate in liquid scintillant.

and extends into intron 1 of the TGF $\alpha$ gene, was subcloned into the pBluescript vector (Stratagene), and the resulting recombinant plasmid was digested with either SspI or DraIII. These linearized DNAs were then tested for their ability to direct specific transcription in runoff assays in the presence of nuclear extracts $(2,11)$ derived from transformed human HeLa cells. Since the SspI cleavage site is more distal to the HindIII-XbaI insert than is the DraIII cleavage site, specific initiation of transcription on the SspIcleaved template should result in products that are correspondingly larger than those observed with the DraIIIcleaved template. Transcription of both templates produced two prominent transcripts whose sizes were appropriately shifted and, in each case, consistent with transcription initiation at sites within the HindIII-XbaI insert (Fig. 6A). The fidelity of transcription in vitro was further examined by primer extension analysis of nonradioactive products derived from the $S s p I$-cleaved template. Figure $6 \mathrm{~B}$, lane 2, shows the familiar pattern of $5^{\prime}$ ends obtained with GP6TB poly(A) ${ }^{+}$RNA when the RT1 primer was used. Comparison of extension products obtained with the in vitro transcription

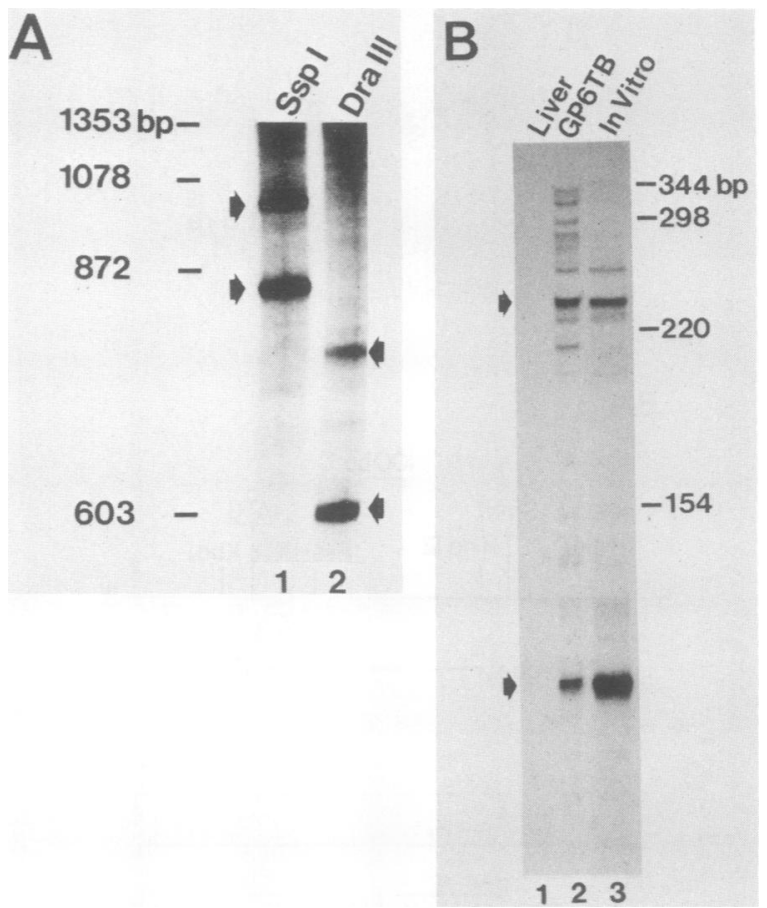

FIG. 6. Transcription in vitro of TGF $\alpha$-pBluescript vectors. (A) The HindIII-XbaI fragment from the 5'-flanking region (see Fig. 4B) was subcloned into pBluescript, and the resulting plasmid was cleaved with either $S s p I$ or DraIII. Linearized plasmid was transcribed in vitro in the presence of nuclear extract derived from HeLa cells, and products were analyzed on a $4 \%$ acrylamide-urea gel as described in Materials and Methods. The migration of HaeIII-cut $\phi \mathrm{X174}$ markers is shown, and the positions of prominent transcription products are marked by arrows. (B) Primer extension analysis of in vitro products. End-labeled RT1 primer was hybridized to $10 \mu \mathrm{g}$ of poly(A) ${ }^{+}$RNA from rat liver or GP6TB cells or the products of an in vitro transcription and treated as described in Fig. 4C and Materials and Methods. The migration of Hinf1-cut pBR322 markers is shown. bp, Base pairs.

products (lane 3) revealed an identical pattern of predominant bands, as well as some minor products. With a longer exposure of the autoradiogram shown in Fig. $6 \mathrm{~B}$, all of the minor bands that were obtained with endogenous TGF $\alpha$ transcripts could also be detected with the in vitro transcripts (data not shown).

Taken together, the results of the transient-expression and in vitro transcription assays indicate that the genomic sequences that flank the mRNA $5^{\prime}$ ends include the TGF $\alpha$ promoter and suggest that the multiple $5^{\prime}$ ends are the result of heterogeneous initiation of transcription at this promoter. Despite the apparent difference in the number of transcription start sites, these data are consistent with the report that the analogous human sequences also contain promoterlike activity as demonstrated by transient-expression assays (17).

Characterization of the TGF $\alpha 5^{\prime}$-flanking sequences. The nucleotide sequence of a 650 -base-pair region that precedes the translational initiation codon was determined and is shown in Fig. 7. This region demonstrates a high $\mathbf{G}+\mathrm{C}$ content $(70 \%)$ that is especially marked in the $3^{\prime}$ portion, which includes the various transcription start sites. In addition, it contains three potential SP1-binding sites, several imperfect indirect repeats, and elements of potential AP2binding sites. However, this region is most notable for its lack of recognizable promoter elements, including CCAAT 
SmaI

-651 GGTGGCAGGTGTCCCGGGGTGGCATGGATGGGGACACAGGTGGAAATTCGACTTAAATGAGTATTTGGCTGACTATGGA

HindIII

-571 GAAGCTTTTCTTGGTCAAGTCTTCCCAGGTGGCTGGCTAAGCTCGTGGGTCTCCAGGCTCCTGCTCAAGAGTGTCGTGG

-491 AGAAGCCCCTAGCACAGGTGACTAACCTGGGCGACTCCGCTCTGCCGCCTACAGCCTGGACGCGGCTACTGCGCAGGGGA

-411 CTCGGGCGGCGACCCTGGGCGCGAGCACTGCAGGGAGGTGTCTGAAGCCCGGCGCTTCCTGCCTGGCCCTTGGCCCAGGG

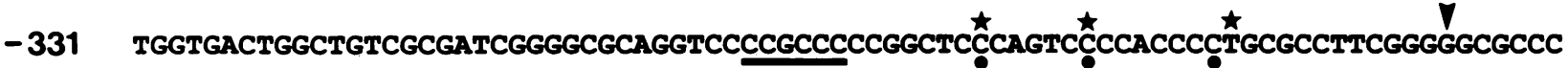

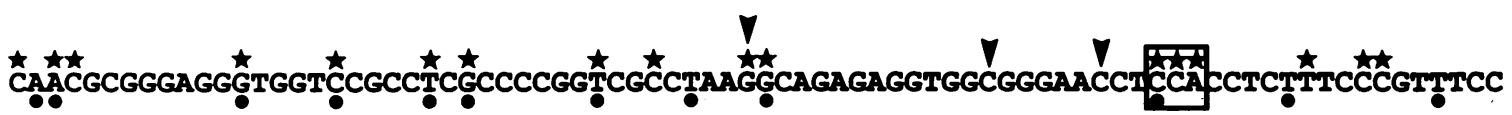

$-171$

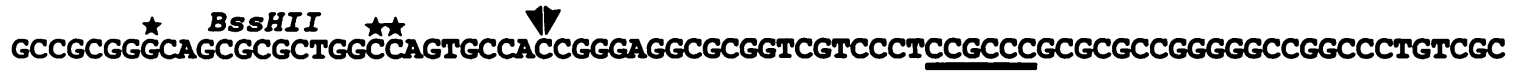

$+1$ -11 GCGCTCGgat ATG GTC CCC GCG GCC GGA CAG CTC GCT CTG CTA GCG CTG G gtacgtaggcaaca
Met Val Pro Ala Ala Gly GIn Leu Ala Leu Leu Ala leu

XbaI

+55 ctcgatgtcccoggggetctaga....

FIG. 7. Nucleotide sequence of the rat TGF $\alpha$ promoter region. Sequence is numbered relative to the first nucleotide of the initiating codon. The 5 ' ends of six independently cloned cDNAs are marked $(\nabla)$. The 5'-most cDNA was isolated from a library whose synthesis had been primed with an oligonucleotide that was complementary to a portion of the $5^{\prime}$ untranslated region directly upstream from the initiation codon. The $5^{\prime}$ ends of endogenous TGF $\alpha$ mRNA as revealed by primer extension ( $\star$ ) or S1 nuclease analysis ( $(\theta)$ are shown, and two prominent transcription start sites are boxed. Potential SP1-binding sites are underlined, and the locations of several restriction enzyme recognition sites are indicated (note that the locations of two additional, $3^{\prime}$-distal BssHII sites are not shown). The nucleotide sequence of intron 1 is designated by lowercase letters. This sequence will appear in the EMBL, GenBank, and DDBJ nucleotide sequence data bases under the accession number M31075.

or TATA boxes. This latter fact may be consistent with the extreme heterogeneity of transcriptional initiation, since the TATA box is generally believed to direct RNA polymerase II to a defined start position (19). Thus, heterogeneous initiation in the absence of an obvious TATA element is a characteristic which the rat TGF $\alpha$ promoter shares with a large number of other promoters, including that of the human epidermal growth factor receptor gene (16). It is surprising, therefore, that the human TGF $\alpha$ promoter was recently reported to direct transcription from a single start site. This species difference may be explained, in part, by the finding that although the rat and human 5 '-flanking sequences are highly conserved (Fig. 7) (17), the human sequence nevertheless contains a larger number of potential SP1-binding sites. However, that these sites are, indeed, bound by SP1 has not yet been established.

Another notable feature of the rat TGF $\alpha$ promoter is the apparent absence of other transcriptional regulatory elements. Thus, although expression of TGF $\alpha$ mRNA is regulated by estrogens and TPA in several cell lines and tissues, the 5 '-flanking region shown in Fig. 7 does not appear to contain recognizable estrogen-responsive (23) or TPA-responsive $(35,42)$ elements. This latter fact, together with the finding that the TPA induction of TGF $\alpha$ mRNA in GP6ac cells is distinct from that of c-myc and c-fos, in terms of both the time course and sensitivity to protein synthesis inhibitors, suggests that regulation of TGF $\alpha$ mRNA by these agents may be indirectly mediated by other activities. Whether this hypothesis is correct or, instead, the responsive elements for these agents reside elsewhere in the gene has yet to be determined. The cloning and characterization of the rat gene and its promoter, as described here, provide valuable tools with which to dissect the molecular regulation of this gene.

\section{ACKNOWLEDGMENTS}

We are grateful to Shannon Kenney and Elizabeth Holley-Guthrie for their assistance in establishing the transient-expression assay and to Wayne Litaker and Jane Badley for helpful advice in preparing the cosmid library. In addition, we thank Frank Furnari and Jean Kahn for technical assistance; Stan McKnight, Al Baldwin, and Ralph Snodgrass for helpful discussions; and Joe Grisham and George Michalopoulos for providing cell lines. We thank Shelley Earp and Noreen Luetteke for a critical reading of the manuscript.

This work was supported by Public Health Service grant CA43793 (to D.C.L.) from the National Institutes of Health and American Cancer Society grant CD317A (to J.C.A.). D.C.L. and J.C.A. are recipients of Junior Faculty Awards from the American Cancer Society. A.J.B. is the recipient of National Research Service Award CA08519.

\section{LITERATURE CITED}

1. Arteaga, C. L., A. R. Hanauske, G. M. Clark, C. K. Osborne, P. Hazarika, R. L. Pardue, F. Tio, and D. D. Von Hoff. 1988. 
Immunoreactive $\alpha$ transforming growth factor activity in effusions from cancer patients as a marker of tumor burden and patient prognosis. Cancer Res. 48:5023-5028.

2. Blake, M. C., and J. C. Azizkhan. 1989. Transcription factor E2F is required for efficient expression of the hamster dihydrofolate reductase gene in vitro and in vivo. Mol. Cell. Biol. 9:4994-5002.

3. Blin, N., and D. W. Stafford. 1976. A general method for isolation of high molecular weight DNA from eukaryotes. Nucleic Acids Res. 3:2303-2308.

4. Brachmann, R., P. B. Lindquist, M. Nagashima, W. Kohr, T. Lipari, M. Napier, and R. Derynck. 1989. Transmembrane TGF- $\alpha$ precursors activate EGF/TGF $\alpha$ receptors. Cell 56:691700.

5. Bringman, T. S., P. B. Lindquist, and R. Derynck. 1987. Different transforming growth factor- $\alpha$ species are derived from a glycosylated and palmitoylated transmembrane precursor. Cell 48:429-440.

6. Coffey, R. J., Jr., R. Derynck, J. N. Wilcox, T. S. Bringman, A. S. Goustin, H. L. Moses, and M. R. Pittelkow. 1987. Production and auto-induction of transforming growth factor- $\alpha$ in human keratinocytes. Nature (London) 328:817-820.

7. Derynck, R., D. V. Goeddel, A. Ullrich, J. U. Gutterman, R. D. Williams, T. S. Bringman, and W. H. Berger. 1987. Synthesis of messenger RNAs for transforming growth factors $\alpha$ and $\beta$ and the epidermal growth factor receptor by human tumors. Cancer Res. 47:707-712.

8. Derynck, R., A. B. Roberts, M. E. Winkler, E. Y. Chen, and D. V. Goeddel. 1984. Human transforming growth factor- $\alpha$ : precursor structure and expression in E. coli. Cell 38:287-297.

9. Dickson, R. B., S. E. Bates, M. E. McManaway, and M. E. Lippman. 1986. Characterization of estrogen responsive transforming activity in human breast cancer cell lines. Cancer Res. 46:1707-1713.

10. Dickson, R. B., A. Kasid, K. K. Huff, S. E. Bates, C. Knabbe, D. Bronzert, E. P. Gelmann, and M. E. Lippman. 1987. Activation of growth factor secretion in tumorigenic states of breast cancer induced by $17 \beta$-estradiol or v-Ha-ras oncogene. Proc. Natl. Acad. Sci. USA 84:837-841.

11. Dignam, J. D., R. L. Lebovitz, and R. G. Roeder. 1983. Accurate transcription initiation by RNA polymerase II in a soluble extract from isolated mammalian nuclei. Nucleic Acids Res. 11:1475-1489.

12. Earp, H. S., J. R. Hepler, L. A. Petch, A. Miller, A. R. Berry, J. Harris, V. W. Raymond, B. K. McCune, L. W. Lee, J. W. Grisham, and T. K. Harden. 1988. Epidermal growth factor (EGF) and hormones stimulate phosphoinositide hydrolysis and increase EGF receptor protein synthesis and mRNA levels in rat liver epithelial cells. J. Biol. Chem. 263:13868-13874.

13. Greene, J. M., and K. Struhl. 1989. Analysis of RNA structure and synthesis, p. 4.6.1-4.6.13. In F. M. Ausubel, R. Brent, R. E. Kingston, D. D. Moore, J. G. Seidman, J. A. Smith, and K. Struhl (ed.), Current protocols in molecular biology. John Wiley \& Sons, Inc., New York.

14. Han, V. K. M., E. S. Hunter III, R. M. Pratt, J. G. Zedegui, and D. C. Lee. 1987. Expression of rat transforming growth factor alpha mRNA during development occurs predominantly in the maternal decidua. Mol. Cell Biol. 7:2335-2343.

15. Ignotz, R. A., B. Kelly, R. J. Davis, and J. Massagué. 1986. Biologically active precursor for transforming growth factor type $\alpha$ released by retrovirally transformed cells. Proc. Natl. Acad. Sci. USA 83:6307-6311.

16. Ishii, S., Y.-H. Xu, R. H. Stratton, B. A. Roe, G. T. Merlino, and I. Pastan. 1985. Characterization and sequence of the promoter region of the human epidermal growth factor receptor gene. Proc. Natl. Acad. Sci. USA 82:4920-4924.

17. Jakobovits, E. B., U. Schlokat, J. L. Vannice, R. Derynck, and A. D. Levinson. 1988. The human transforming growth factor alpha promoter directs transcription initiation from a single site in the absence of a TATA sequence. Mol. Cell. Biol. 8:55495554.

18. Jakowlew, S. B., P. Kondaiah, P. J. Dillard, M. B. Sporn, and A. B. Roberts. 1988. A novel low-molecular-weight ribonucleic acid (RNA) related to transforming growth factor $\alpha$ messenger RNA. Mol. Endocrinol. 2:1056-1063.

19. Jones, N. C., P. W. J. Rigby, and E. B. Ziff. 1988. Trans-acting protein factors and the regulation of eukaryotic transcription: lessons from studies on DNA tumor viruses. Gene Dev. 2: 267-281.

20. Kelly, K., B. H. Cochran, C. D. Stiles, and P. Leder. 1983. Cell-specific regulation of the c-myc gene by lymphocyte mitogens and platelet-derived growth factor. Cell 35:603-610.

21. Kenney, S., J. Kamine, E. Holley-Guthrie, E. C. Mar, J. C. Lin, D. Markovitz, and J. Pagano. 1989. The Epstein-Barr virus immediate-early gene product, BMLF1, acts in trans by a posttranscriptional mechanism which is reporter gene dependent. J. Virol. 63:3870-3877.

22. Kingston, R. E. 1989. Primer extension, p. 4.8.1.-4.8.3. In F. M. Ausubel, R. Brent, R. E. Kingston, D. D. Moore, J. G. Seidman, J. A. Smith, K. Struhl (ed.), Current protocols in molecular biology. John Wiley \& Sons, Inc., New York.

23. Klein-Hitpass, L., M. Schorpp, U. Wagner, and G. U. Ryfiel. 1986. An estrogen-responsive element derived from the $5^{\prime}$ flanking region of the Xenopus vitellogenin A2 gene functions in transfected human cells. Cell 46:1053-1061.

24. Kruijer, W., J. A. Cooper, T. Hunter, and I. M. Verma. 1984. PDGF induces rapid but transient expression of the c-fos gene. Nature (London) 312:711-716.

25. Kudlow, J. E., A. W. C. Leung, M. S. Kobrin, A. J. Paterson, and S. L. Asa. 1989. Transforming growth factor- $\alpha$ in the mammalian brain. Immunohistochemical detection in neurons and characterization of its mRNA. J. Biol. Chem. 264:38803883.

26. Lee, D. C., T. M. Rose, N. R. Webb, and G. J. Todaro. 1985. Cloning and sequence analysis of a cDNA for rat transforming growth factor- $\alpha$. Nature (London) 313:489-491.

27. Liu, C., M.-S. Tsao, and J. W. Grisham. 1985. Transforming growth factors produced by normal and neoplastically transformed rat liver cells in culture. Cancer Res. 48:850-855.

28. Liu, S. C., B. Sanfilippo, I. Perroteau, R. Derynck, D. S. Salomon, and W. R. Kidwell. 1987. Expression of transforming growth factor $\alpha$ (TGF $\alpha$ ) in differentiated rat mammary tumors: estrogen induction of TGF- $\alpha$ production. Mol. Endocrinol. 1:683-692.

29. Luetteke, N. L., G. K. Michalopoulos, J. Teixido, R. Gilmore, J. Massague, and D. C. Lee. 1988. Characterization of high molecular weight transforming growth factor $\alpha$ produced by rat hepatocellular carcinoma cells. Biochemistry 27:6487-6494.

30. Marquardt, H., M. W. Hunkapiller, L. E. Hood, and G. J. Todaro. 1984. Rat transforming growth factor type 1: structure and relation to epidermal growth factor. Science 223:1079-1082.

31. Mueller, S. G., M. S. Kobrin, A. J. Paterson, and J. E. Kudlow. 1989. Transforming growth factor- $\alpha$ expression in the anterior pituitary gland: regulation by epidermal growth factor and phorbol ester in dispersed cells. Mol. Endocrinol. 3:976-983.

32. Muller, R., R. Bravo, J. Burckhardt, and T. Curran. 1984. Induction of c-fos gene and protein by growth factors precedes activation of c-myc. Nature (London) 312:716-720.

33. Novicki, D. L., R. L. Jirtle, and G. K. Michalopoulos. 1983. Establishment of two rat hepatoma cell strains produced by carcinogen initiation, phenobarbital promotion protocol. In Vitro (Rockville) 19:191-202.

34. Pittelkow, M. R., P. B. Lindquist, R. T. Abraham, R. GravesDeal, R. Derynck, and R. J. Coffey, Jr. 1989. Induction of transforming growth factor- $\alpha$ expression in human keratinocytes by phorbol esters. J. Biol. Chem. 264:5164-5171.

35. Prywes, R., and R. G. Roeder. 1986. Inducible binding of a factor to the c-fos enhancer. Cell 47:777-784.

36. Raymond, V. W., D. C. Lee, J. W. Grisham, and H. S. Earp. 1989. Regulation of transforming growth factor $\alpha$ messenger RNA expression in a chemically transformed rat hepatic epithe- 
lial cell line by phorbol ester and hormones. Cancer Res. 49:3608-3612.

37. Salomon, D. S., I. Perroteau, W. R. Kidwell, J. Tam, and R. Derynck. 1987. Loss of growth responsiveness to epidermal growth factor and enhanced production of alpha-transforming growth factors in ras-transformed mouse mammary epithelial cells. J. Cell. Physiol. 130:397-409.

38. Samsoondar, J., M. S. Kobrin, and J. E. Kudlow. 1986. a transforming growth factor secreted by untransformed bovine anterior pituitary cells in culture. I. Purification from conditioned media. J. Biol. Chem. 261:14408-14413.

39. Sanger, F., S. Nicklen, and A. R. Coulson. 1977. DNA sequencing with chain-terminating inhibitors. Proc. Natl. Acad. Sci. USA 74:5463-5467.

40. Steinmetz, M., D. Stephen, G. R. Dastoornikoo, E. Gibb, and R. Romaniuk. 1985. Methods in molecular immunology: chromosomal walking in the major histocompatibility complex, p. 1-18. In I. Lefkovits and B. Pernis (ed.), Immunological methods, vol. III. Academic Press, Inc., New York.

41. Teixidó, J., and J. Massagué. 1988. Structural properties of a soluble bioactive precursor for transforming growth factor- $\alpha$. J. Biol. Chem. 263:3924-3929.

42. Treisman, R. 1986. Identification of a protein-binding site that mediates transcriptional response of the c-fos gene to serum factors. Cell 46:567-574

43. Tsao, M.-S., J. W. Grisham, K. G. Nelson, and J. D. Smith. 1985. Phenotypic and karyotypic changes induced in cultured rat hepatic epithelial cell that express the "oval" cell phenotype by exposure to $n$-methyl- $n$-nitro- $n$-nitrosoguanidine. Am. J. Pathol. 118:306-315.

44. Tsao, M.-S., J. D. Smith, K. G. Nelson, and J. W. Grisham. 1984. A diploid epithelial cell line from normal adult rat liver with phenotypic properties of oval cells. Exp. Cell Res. 154: 38-52.

45. Wilcox, N. C., and R. Derynck. 1988. Localization of cells synthesizing transforming growth factor-alpha mRNA in the mouse brain. J. Neurosci. 8:1901-1904.

46. Wong, S. T., L. F. Winchell, B. K. McCune, H. S. Earp, J. Teixidó, J. Massagué, B. Herman, and D. C. Lee. 1989. The TGF $\alpha$ precursor expressed on the cell surface binds to the EGF receptor on adjacent cells, leading to signal transduction. Cell 56:495-506.

47. Yeh, Y.-C., J.-F. Tsai, L.-Y. Chuang, H.-W. Yeh, J.-H. Tsai, D. L. Florine, and J. P. Tam. 1987. Elevation of transforming growth factor $\alpha$ and its relationship to the epidermal growth factor and $\alpha$-fetoprotein levels in patients with hepatocellular carcinoma. Cancer Res. 47:896-901. 